\title{
HOW CCS PROJECTS ARE DEVELOPED IN SELECTED COUNTRIES?
}

\author{
Romario de Carvalho Nunes* and Hirdan Katarina de Medeiros Costa \\ Institute of Energy and Environment, University of São Paulo, São Paulo, Brazil
}

\section{ARTICLE INFO}

\section{Article History:}

Received $10^{\text {th }}$ April, 2021

Received in revised form

$20^{\text {th }}$ May, 2021

Accepted $06^{\text {th }}$ June, 2021

Published online $28^{\text {th }}$ July, 2021

\section{Key Words:}

Capture, Carbon Use and Storage, Technical and historical aspects of CCS, Worldwide situation for CCS, Carbon storage facilities.

\begin{abstract}
The present work will address, among other aspects, the technical context, history, and importance of the use of CCS in the current world situation. This technology is highlighted as a search for technological solutions to reduce greenhouse gas emissions and consequent mitigation of global warming. The history and motivators of the use of technology and its challenges faced over the years will be objects of study, and the storage facilities will be described, classifying them by their storage capacity, their operational status, and the development of new facilities projects. It will also be covered critical analysis regarding the use of these facilities in some countries, using the latest data from specialized entities and agencies, such as the International Energy Agency (IEA) and the Global CCS Institute. In the end, there is a description through a literature review of the methodology used for the technical evaluation of reservoirs conducive to carbon dioxide storage using the Brazilian case study.
\end{abstract}

Copyright (C) 2021, Romario de Carvalho Nunes and Hirdan Katarina de Medeiros Costa. This is an open access article distributed under the Creative Commons Attribution License, which permits unrestricted use, distribution, and reproduction in any medium, provided the original work is properly cited.

Citation: Romario de Carvalho Nunes and Hirdan Katarina de Medeiros Costa. "How CCS projects are developed in selected countries?", International Journal of Development Research, 11, (07), 48829-48834.

\section{INTRODUCTION}

In the contemporary context, the theme of climate change mitigation is an object of international relevance. In the meantime, companies and governments are looking for alternatives to deal with climate change, caused mainly by global warming, given the opportunity to intensify the emission of greenhouse gases. Among projects capable of mitigating the emission of these gases, there is a technology called Carbon Capture and Storage (CCS). The CCS technology comprises the phases of carbon dioxide capture (mainly in industrial plants such as metallurgy, cement, and refineries), use of carbon (as in the plant greenhouse industry), and storage (either in salt caves or onshore wells) / offshore). The Intergovernmental Panel on Climate Change: IPCC (2005) defines the capture and storage of $\mathrm{CO} 2$ in geological reservoirs as a process that consists of the separation of $\mathrm{CO} 2$, emitted by stationary sources related to energy production and also from industrial plants, in the transport of this $\mathrm{CO} 2$ and its long-term storage in geological reservoirs, isolating it from the atmosphere. It is possible to separate the $\mathrm{CO} 2$ emitted from the burning of fossil fuels, process it into its liquid form, and transport it by pipeline, highways, or by sea to geological reservoirs such as deactivated mines, oil fields, or other places where CO2 can be stored (CÂMARA, 2011). Studies by the Intergovernmental Panel on Climate Change - IPCC (2005), the Forum of the Main Economies for Energy and Climate - MET
(2009), and the International Energy Agency - AIE (2010) pointed out the need for the actual implementation of the CCS for energy generation moved to fossils and industrial processes to minimize the costs expected to meet the reduction targets for greenhouse gases (EASAC 2013). The CCS technology in Brazil will be relevant for the industry and can be crucial for developing some fields of the "Presalt" since some wells showed CO2 concentrations well above those found in the Campos Basin (BECK, 2011). In general, the presence of $\mathrm{CO} 2$ in the hydrocarbon found in the fields of the Pre-Salt Cluster is between 8 and $12 \%$, considered significant in comparison with the composition of hydrocarbons in other locations (CÂMARA, 2011). However, it is necessary to research to locate $\mathrm{CO} 2$ storage areas associated with the study and deepening of geological knowledge, the verification of legal requirements inherent to the activity to be carried out, the technology applied in the implementation and operation of the project, as well as the mapping risks involved (NUNES; COSTA, 2019). In this sense, to locate CO2 storage zones, according to KETZER et al. (2016), the geological reservoirs must meet requirements that guarantee the integrity of the storage location and the efficiency of the activity, such as capacity and adequate injectivity rates (permeability in the vicinity of injection wells), containment capacity of the sealing rock to prevent upward migration of $\mathrm{CO} 2$ and geological environment geochemically and geomechanically stable and, consequently, safe. Also, the characteristics of the basin must include adequate stratigraphy and reservoir depth, favorable 
geothermal and hydrodynamic regimes, and low seismic activity (KETZER et al., 2016). In this sense, the basin's resources must be analyzed for the occurrence of oil and gas for EOR (Advanced Petroleum Recovery), a safe distance from freshwater aquifers, and availability of deep salt formations (KETZER et al., 2016). Therefore, this article proposes a reading of the technology context in CCS in Brazil associated with the overview of the history of the use of CCS in the world and the context to which the technology was developed over time until its use in the current situation, to which it will be dedicated a separate chapter. It will be presented to the reader what were the motivators that led to the implantation of the CCS in several countries, highlighting those that have carbon dioxide storage projects incomplete execution and the estimated amount stored annually by the government. Storage facility projects will be highlighted in a chapter dedicated to verifying which facilities exist in the world, where they are located, what their operating status is, and demonstrating existing construction projects and their respective phase. A critical analysis will also be carried out in the chapter related to the data collected, showing the motivation for building these facilities in certain countries to the detriment of others. The article will also bring technical aspects about Brazilian reservoirs and basins and analyses related to the probability of developing the use of CCS in each of these basins.

History of the use of Technology: According to Bachu et al. (1994, p. 551), "the geological storage of $\mathrm{CO} 2$ as a measure to mitigate greenhouse gas emissions was initially proposed in the 1970s, but only in the $1990 \mathrm{~s}$, when the idea gained credibility through work developed by scientists, there have been advances in research and development. ". Today, according to Metz et al. (2005, p.211), "all major oil, coal ore and electricity generation companies study, to mitigate their environmental effects, this form of geological storage, this being a technology with great potential to make in the face of environmental problems. "

The storage of $\mathrm{CO} 2$ in the earth's crust has been a natural process since its creation. However, from the 1970s in the USA, this storage began to be induced by man. To facilitate the collection of oil, the $\mathrm{CO} 2$ resulting from the refining process was and continues to be, placed in the reservoirs, thus causing the expulsion of crude oil. Initially not being the primary objective of this process to preserve the environment, this process has been used in the oil industry worldwide, thus preventing any $\mathrm{CO} 2$ from being released into the atmosphere. (KETZER, 2014). The geological storage of CO2 as a measure to mitigate greenhouse gas emissions was initially proposed in the 1970s. Still, research was not developed until the 1990s, when the idea gained credibility through work developed by individual scientists or working groups. Today, large oil, coal ore, and electricity generation companies study this form of geological storage, intending to mitigate its environmental effects. For this reason, as of the 1990s, this technology changed from a concept of little interest to technology with great potential to face environmental problems (KETZER, 2014). In the scenario of implementation of this technology, Kheshgi et al. (2012) state that some expectations for the development of CCS have not been realized due to factors such as the lack of implementation of climate policies in many parts of the world, generating low incentives for CCS; the variation of the CCS price, reaching values even higher than initially estimated; and the social barrier regarding the public acceptance of the CCS implementation.

CCS IN THE CURRENT WORLD CONJUNCTURE: In the oil and gas industry, CCS technology is developed in oil and gas reservoirs as a way of stimulating the production of hydrocarbons in mature fields or that require increased pressure in the reservoir to increase the productivity of the extraction wells. Sometimes the injection may not be just carbon dioxide in high concentrations, but also mixtures composed mostly of atmospheric air and even natural gas called underground storage of natural gas (e.g., GORAIEB et al. 2005 and EPE 2018). In the oil energy system, CO2 storage consists of the injection of $\mathrm{CO} 2$ into the reservoir rock, representing one of the special secondary recovery methods of the oil. This special recovery is also known as advanced or improved and referred to in English as enhanced oil recovery (EOR). From the fifty-five largest CCS projects in the world, the Global CCS Institute (2014) states that the EOR-CO2 mechanism would have a participation of around $58 \%$ globally. This $\mathrm{CO} 2$ injection technology ends up being considered a safe alternative for the storage of this gas and can be proven with the operation of dozens of cases, for the exploration of hydrocarbons, in several geological contexts (ZOBACK 2007). However, this technology developed for specific purposes and of little prominence ended up having a great worldwide projection due to recent initiatives (from implantation) of stockpiling $\mathrm{CO} 2$ with the exclusive purpose of storing the so-called greenhouse gases (GHG) as a function of climate change mitigation technologies.

According to data from the IEA (2009), it is predicted that by 2030 more than $80 \%$ of primary energy resources will be associated with fossil fuels, generating the maintenance of the current situation of increasing emission of greenhouse gases. Also, forecasts of an increase in world energy demand for the coming years, mainly associated with population growth and the industrialization process, lead to estimates of increased emissions of up to $85 \%$, according to studies by the Global CCS Institute (2014). Although some initiatives seek to unlink the increase in the concentration of carbon dioxide in the atmosphere with systemic warming of the planet, a relatively much larger portion of the scientific community accepts the correlation between the two factors as a causal link. The finding of global atmospheric warming can be evidenced by analyzing the historical variation of $\mathrm{CO} 2$ concentration ( $\mathrm{ppm}$ ) over the last 400 thousand years, observing the discrepant increase in this concentration in 1950, as can be seen in Figure 2. The relationship with In 1988, regardless of the causative and triggering processes, it became the target of a global research initiative entitled Intergovernmental Panel on Climate Change, better known by the acronym IPCC (from its English name Intergovernmental Panel on Climate Change), the result of the initiative of the United Nations Environment Program (UNEP) and the World Meteorological Organization (WMO).

\section{$\mathrm{CO}_{2}$ during ice ages and warm periods for the past 800,000 years}

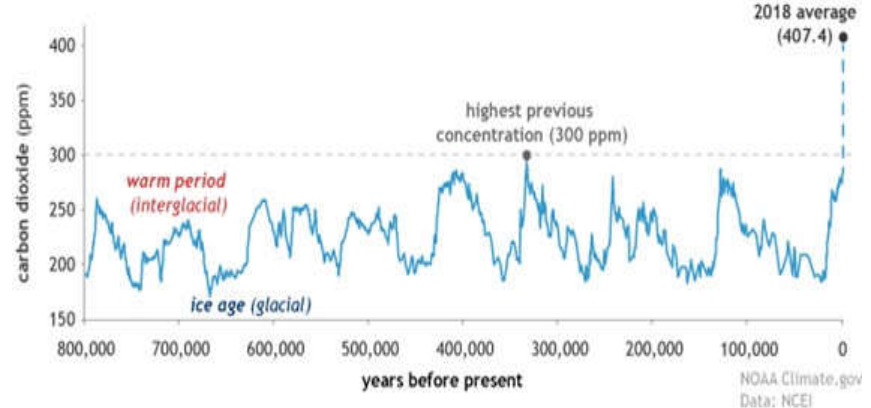

Source: NOAA - National Oceanic and Atmospheric Administration

\section{Figure 1. Global concentrations of carbon dioxide in the atmosphere (CO2) in parts per million (ppm) over the past $\mathbf{8 0 0 , 0 0 0}$ years}

At the forefront of mitigation, whose initiatives up to the fourth IPCC report (2014) were to promote sustainability, mainly associated with a change in the energy matrix for renewable sources, as of 2014 it started to assess that changes in habits and advances technological achievements would not be enough to avoid the scenarios with the most significant impact by climate change, beginning to promote bolder goals and the need to capture greenhouse gases (GHG) from the atmosphere, associated with their use and storage. These findings from the 5th IPCC report, associated with growing initiatives by the international community, culminated in the Paris Agreement in 2015, setting targets for the concentration of GHG emissions into the atmosphere, as well as acceptable concentrations over the decades of the 21 st century. Regarding carbon storage facilities, recent data made available by the Global CCS Institute show that 18 CCS projects are currently in operation on a large scale worldwide, associated with capture of 37 million tons of $\mathrm{CO} 2$ per year (Mtpa), equivalent to the activity of 8 million cars. Also, according to The Global Status of 
CCS 2017, more than 220 million tons of CO2 were stored cumulatively by the year 2017. The storage potential is still not entirely clear, and there are doubts in determining how large the storage capacity is global. It is estimated that in deactivated oil and gas reservoirs, there is a storage capacity between 675 and 900 Gton of $\mathrm{CO} 2$. In salt formations, estimates point to a capacity of at least 1000 Gton, and these locations may represent a capacity ten times greater (METZ et al., 2005). Data were collected from the Global CCS Institute's CO2RE database in October 2018. Regarding the amount of $\mathrm{CO} 2$ captured, according to the International Energy Agency (IEA), globally, more than 30 million tons of $\mathrm{CO} 2$ is captured in large-scale CCS facilities for use or storage, more than $70 \%$ in South America. North. Figure 4 shows the dispersion of this capture, with highlights for the USA ( 24.85 Mtpy - 10 projects) and Australia (4 Mtpy - 1 project). Brazil has one project and an annual catch of 1 Mtpy.

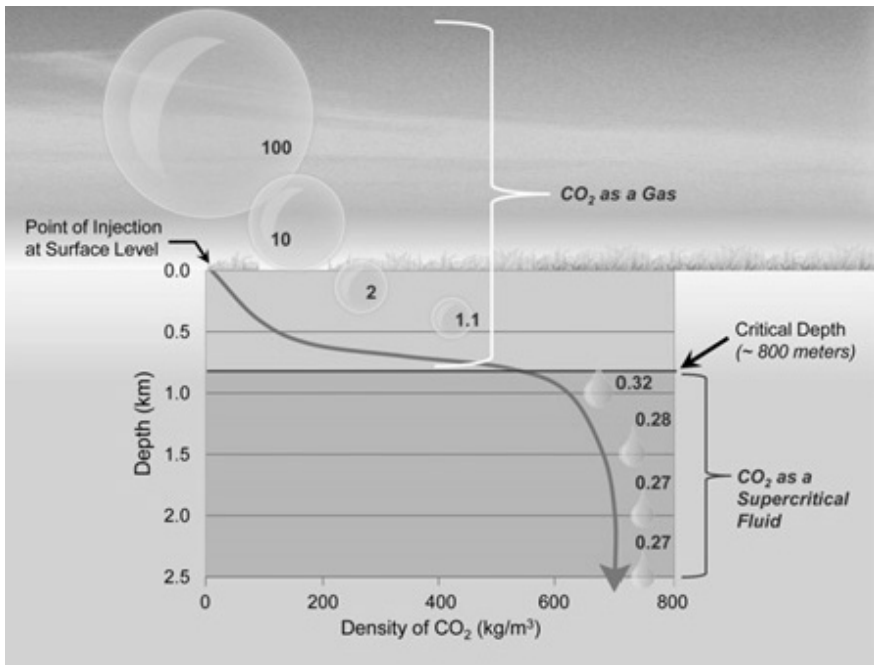

Source: National Energy Technology Laboratory.

Figure 2. Behavior of $\mathrm{CO} 2$ subjected to high pressures

\section{TECHNICAL ANALYSIS OF BRAZILIAN RESERVOIRS AND BASINS FOR CARBON STORAGE}

The geological storage of $\mathrm{CO} 2$ involves the injection of gas into geological formations at great depths using CCS technology, with emphasis on gas injection in oil and gas fields, deep salt formations, and coal layers (IEA, 2010). However, each type of reservoir has its peculiarities (KETZER et al., 2016). In most cases, the injected CO2 will be in a supercritical state (KETZER et al., 2016). In this condition, $\mathrm{CO} 2$ acquires a typical density of liquids, thus occupying a smaller pore volume, leading to more efficient storage (KETZER et al., 2016). To guarantee storage in a supercritical state, a minimum estimated depth for a reservoir is about 800 meters (m) (KETZER et al., 2016). A reservoir rock is generally suitable for $\mathrm{CO} 2$ storage when it has high permeability and high porosity (KETZER et al., 2016). Then, the CO2 injected into reservoirs, especially in deep saline formations, will, over time, partially dissolve in the saline groundwater (brine) present in these reservoirs (KETZER et al., 2016). The speed of dissolution will vary according to the geology of the reservoir, temperature and pressure conditions, and composition of the brine (KETZER et al., 2016). This mechanism is known as ionic or solubility trapping and can serve as an additional mechanism to immobilize $\mathrm{CO} 2$ in the reservoir and reduce the risks associated with eventual leakage (KETZER et al., 2016). Dissolved CO2 can also react chemically with rocks and reservoir fluids, causing carbonate precipitation. This process is known as mineral trapping and has the potential to immobilize the injected $\mathrm{CO} 2$ in a solid phase (KETZER et al., 2016). Figure 5 shows the behavior of $\mathrm{CO} 2$ subjected to high pressures when the depth. About Brazil, there is an emphasis on the characteristics and resources of the basins since it constitutes most of the South American Platform, a section of the continental crust that in turn is the most stable part of the South American tectonic plate.

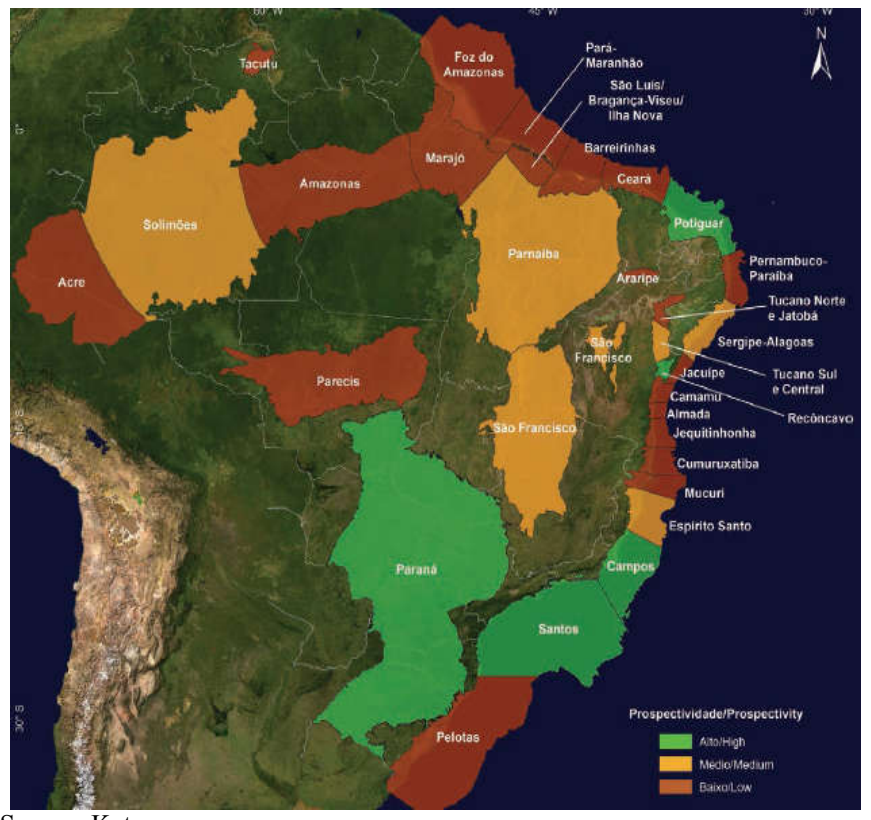

Source: Ketzer

Figure 3. Prospectivity of Brazilian Sedimentary Basins

Ancient igneous and metamorphic rocks formed during the Precambrian period (more than 590 million years ago) form a foundation complex that underlies the entire platform, including Brazil. Subsequent complex movements of the Earth's crust since Precambrian times have created a series of depressions or basins in various parts of Brazil. In total, 31 sedimentary basins occur within the Brazilian territory, covering approximately 6.4 million $\mathrm{km} 2$, about more than $50 \%$ of the Brazilian territory, $75 \%$ of which is located in a terrestrial environment (MILANI et al., 2007). About Brazil, the Campos Basin has significant potential for $\mathrm{CO} 2$ storage, with theoretical capacity estimated at $950 \mathrm{Mt} \mathrm{CO} 2$, with around $75 \%$ of this capacity in the Roncador (28\%), Marlim (18\%), Albacora (17\%), and Barracuda (12\%). This capacity would be sufficient to store the equivalent of 3.5 years of total emissions from Brazilian stationary sources (Ketzer et al., 2014). Sedimentary basins have distinct characteristics that determine the potential for geological storage. Therefore, an assessment of the degree of possibility of prospectivity in Brazilian sedimentary basins represents an essential step in selecting CO2 storage sites (KETZER et al., 2014). Since then, the Brazilian Atlas of CO2 Capture and Geological Storage (KETZER et al., 2016) analyzed all sedimentary basins according to seven criteria related to the stages of a CCS project. The study took into account the following parameters: occurrence of coal deposits, the active production of hydrocarbons, the existence of data on salt formations, theoretical capacity for $\mathrm{CO} 2$ storage $^{1}$, the existence of mature oil and gas fields, associated emission sources ${ }^{2}$ and presence of infrastructure transportation (ducts and terminals). From this, a prospective map was generated through a basin-by-basin analysis, classifying them into three main groups: low, medium, or high prospective for storage, as seen in Figure 6. Due to the absence of hydrocarbon production and the low volume of $\mathrm{CO} 2$ emissions within their limits, most of the North and Northeast basins, as well as the Pelotas basin, in the South, were classified as having "low prospects" for storage of $\mathrm{CO} 2$ (KETZER et al., 2016).

As for the storage capacity within this group, the Amazonas Basin stands out, followed by the Foz do Amazonas Basin, due to its more significant porous volumes. Ceará is the only low-prospective basin with hydrocarbon production. The Mucuri, Pelotas, Tucano Norte, and Jatobá basins are the only ones with a significant number of associated CO2 sources (KETZER et al., 2016). The SergipeAlagoas, Parnaíba, Espírito Santo, São Francisco, Solimões, Tucano Sul and Central basins were classified as "medium" in terms of prospective $\mathrm{CO} 2$ storage projects, since the evaluated criteria are only partially met, or regarding only one or two criteria (KETZER et al., 2016). In this case, the basins have a high storage capacity, the active 
production of hydrocarbons and/or the presence of mature oil fields, and significant proximity to large sources of emissions within the limits of the basin (KETZER et al., 2016). Within this group, the Sergipe-Alagoas Basin was classified as having the greatest potential, despite not having the greatest storage capacity (KETZER et al., 2016). This classification is mainly due to the production of hydrocarbons and the existence of mature fields in this basin, and also to the existence of a pipeline structure and a reasonable number of sources of corresponding emissions ( $38 \mathrm{Mt} \mathrm{CO} 2$ / year) in the vicinity (KETZER et al., 2016). The Paraná, Campos, Santos, Potiguar and Recôncavo sedimentary basins are classified as those with the greatest prospect for $\mathrm{CO} 2$ storage in Brazil, mainly due to the prominent production of hydrocarbons and the presence of mature fields and, in the case of the Paraná Basin, the occurrence of coal deposits (KETZER et al., 2016). The Campos Basin is the largest oilproducing basin in the country. In addition, these basins have a good association between sources and sinks and a network of pipelines for transporting $\mathrm{CO} 2$, which increases their prospects (KETZER et al., 2016). Emissions from sources within these basins (up to the $300 \mathrm{~km}$ zone) reach around $368 \mathrm{Mt} /$ year (KETZER et al., 2016). If only 1,115 industrial plants associated with the Paraná Basin are considered, $\mathrm{CO} 2$ emissions in the region reach $268 \mathrm{Mt} /$ year, with the energy sector being responsible for $49 \%$ of this value, followed by the biomass sector (44\%) ( KETZER et al., 2016). From an economic point of view, the basins of the continental margin stand out as the main producers of hydrocarbons. Among these basins, the Campos Basin is notably the largest producer, accounting for approximately $80 \%$ of national oil production. The Santos Basin will possibly be the main hydrocarbon production area in Brazil from 2025 when the exploration of the Pre-Salt reservoirs increases substantially. (KETZER et al., 2014). For several decades, CO2 has been used as injection fluid for additional recovery of oil \& gas to successfully recover extra oil, given that significant reserves can remain in reservoirs after primary recovery. This technique is known as Enhanced Oil Recovery (EOR) or tertiary recovery. Most of these projects are located in the United States, and a large proportion of the $\mathrm{CO} 2$ used has been obtained from natural accumulations, with a smaller part coming from anthropogenic sources. (KETZER et al., 2016).

CO2-EOR operations have the potential to extend the economic life of individual fields by a decade or more, as proven by several projects where several tens of percent of additional oil reserves have been produced. Typically, a proportion of the injected $\mathrm{CO} 2$ is stored in the reservoir by trapping mechanisms as previously described, while some injected $\mathrm{CO} 2$ is made from the reservoir with oil. The proportion of this 'recycled' $\mathrm{CO} 2$ increases with time but is easily stripped from the oil and re-injected into the reservoir with 'new' CO2 in a closed-loop system. (KETZER et al., 2016). Specifically, in the case of Brazil, $\mathrm{CO} 2$ is currently utilized at a commercial scale by the oil \& gas industry for enhanced oil recovery (EOR), and the country already has one large-scale and integrated CCS project in the Pre-Salt oil fields (KETZER et al., 2016). In general, the characteristics of the hydrocarbon found in the fields of the Pre-salt Cluster are as follows: high API grade, between $28-30^{\circ}$; high gas solution ratio, between $200-300 \mathrm{~m} 3 / \mathrm{m} 3$ and presence of CO2 in the hydrocarbon, between 8 to $12 \%$ (ALMEIDA et al., 2010). The percentage of 8 to $12 \%$ of $\mathrm{CO} 2$ present is considered significant compared to the composition of other hydrocarbons. In view of this reality, Petrobras has been studying options to explore and produce the hydrocarbon found in the Pre-salt viable from the perspective of sustainability. According to Almeida et al. (2010), the following options are being evaluated technically and economically for the use and use of the $\mathrm{CO} 2$ contained in the pre-salt hydrocarbon: EOR in the pre-salt reservoirs; $\mathrm{CO} 2$ storage in saline aquifers; EOR in heavy oil fields in the Santos Basin; the storage of $\mathrm{CO} 2$ in exhausted gas fields; the storage of $\mathrm{CO} 2$ in salt caves to be built in the cluster area; transport of $\mathrm{CO} 2$ to the continent and commercialization of industrial plants (non-geological use/storage option). Although all the alternatives are equally analyzed, the preferred option for the flow of $\mathrm{CO} 2$ present in the Pre-salt hydrocarbon seems to be the reinjection in the reservoirs of the Pre-salt itself, since it can obtain a double benefit in this strategy: the increase in the hydrocarbon recovery factor and verification of the effective storage of the $\mathrm{CO} 2$ produced (ALMEIDA et al., 2010).

CCS PROJECTS IN THE WORLD AND IN BRAZIL: Analyzing the data obtained in 2020 and 2021 by the Global CCS Institute., It is possible to verify that there is a trend in the installation and operation of the facilities in countries that produce a considerable amount of hydrocarbons (Canada, USA, Brazil, China, Saudi Arabia, United Arab Emirates, Algeria, United Kingdom, and Norway), as well as those that refine it in considerable quantities (Canada, USA, Brazil, China, Saudi Arabia, and Japan). The reason would be mainly due to the infrastructure already installed on-site in the case of producers, as well as considerable quantities of $\mathrm{CO} 2$ emissions during refining, in this case, Japan would be an example. The highlight is on account of Australia, which, although it has relatively low production, consumption, and hydrocarbon refining, has a considerable number of installations. The above finding can be confirmed when looking at graphs 1 , which show the number of CCS storage facilities in general as well as the 2021 facility status in the world:

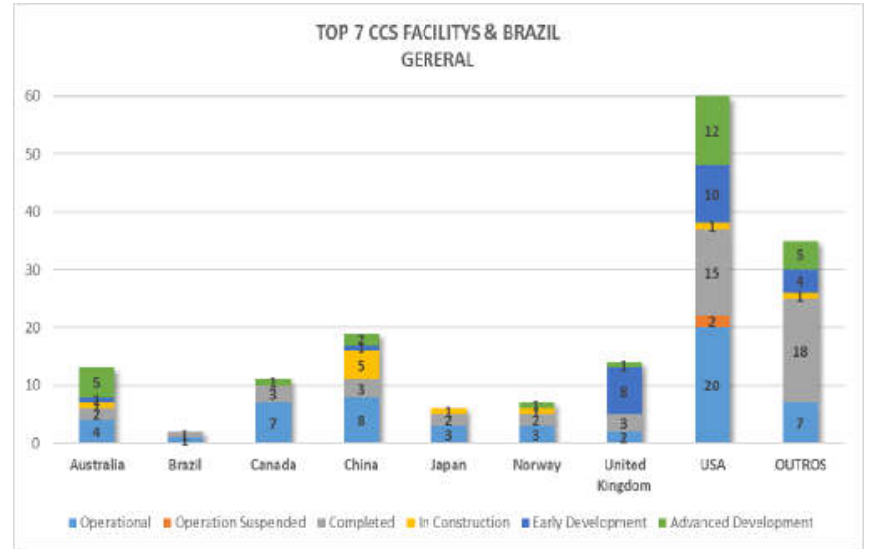

Source: Elaborated by author from Global CCS Institute

\section{Graphic 1. Top 7 CCS Facilitys and Brazil General}

The graph above shows the United States example about the amount of $\mathrm{CO} 2$ storage facilities in the world $(36 \%)$ and negligible diversification between countries since the seven countries above (excluding Brazil) concentrate around $77.8 \%$ of the global facilities. The graph also shows a large concentration of operational facilities in 2021 - around 55 installations - and complete - about 49 installations. There are currently 15 countries that have $\mathrm{CO} 2$ storage facilities in operation worldwide, a considerable part $(36 \%)$ in the United States, followed by China (14.5\%) and Canada (13\%), as shown in Graph 2. Brazil has modest participation in this list, having only one installation in operation, although it is considered a large-scale installation.

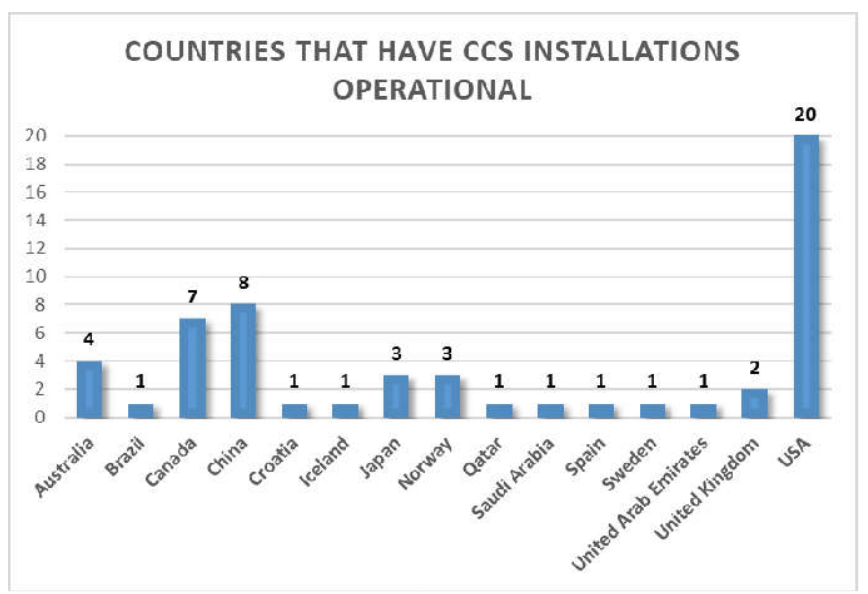

Source: Elaborated by author from Global CCS Institute

Graphic 2. Countries that have CCS installations operational 
Table 1. Summary of CO2 Storage Facilities segregated by the operation of these facilities

\begin{tabular}{|c|c|c|c|c|c|c|c|c|c|c|c|c|c|c|c|c|c|c|}
\hline \multirow{3}{*}{ Country } & & & & & \multicolumn{14}{|c|}{ Facility Status } \\
\hline & \multicolumn{4}{|c|}{ Facility } & \multicolumn{2}{|c|}{ Operational } & \multirow{2}{*}{\begin{tabular}{c|} 
Operating \\
2020
\end{tabular}} & \multirow{2}{*}{\begin{tabular}{|c|}
$\begin{array}{c}\text { Operation } \\
\text { Suspended }\end{array}$ \\
2021 \\
\end{tabular}} & \multicolumn{2}{|c|}{ Completed } & \multicolumn{2}{|c|}{$\begin{array}{c}\text { In } \\
\text { Construction }\end{array}$} & \multicolumn{2}{|c|}{$\begin{array}{c}\text { Early } \\
\text { Development }\end{array}$} & \multicolumn{2}{|c|}{$\begin{array}{c}\text { Advanced } \\
\text { Development }\end{array}$} & \multicolumn{2}{|c|}{$\begin{array}{l}\text { Development } \\
\text { Planning }\end{array}$} \\
\hline & 2020 & 2021 & $\%$ & Total & 2020 & 2021 & & & 2020 & 2021 & 2020 & 2021 & 2020 & 2021 & 2020 & 2021 & 2020 & 2021 \\
\hline Algeria & 1 & 1 & 0 & 0,6 & & & & & 1 & 1 & & & & & & & & \\
\hline Australia & 11 & 13 & 18,2 & 7,8 & 4 & 4 & 1 & & 2 & 2 & & 1 & 1 & 1 & 3 & 5 & & \\
\hline Belgium & 2 & 1 & $-50,0$ & 0,6 & & & & & & & 2 & 1 & & & & & & \\
\hline Brazil & 2 & 2 & 0,0 & 1,2 & & 1 & 1 & & 1 & 1 & & & & & & & & \\
\hline Canada & 14 & 11 & $-21,4$ & 6,6 & 4 & 7 & 2 & & 3 & 3 & 3 & & & & 2 & 1 & & \\
\hline China & 28 & 19 & $-32,1$ & 11,4 & 11 & 8 & 2 & & 3 & 3 & 4 & 5 & 5 & 1 & 3 & 2 & & \\
\hline Croatia & 1 & 1 & 0,0 & 0,6 & 1 & 1 & & & & & & & & & & & & \\
\hline Denmark & 2 & 2 & 0,0 & 1,2 & & & & & 2 & 2 & & & & & & & & \\
\hline France & 4 & 3 & $-25,0$ & 1,8 & 1 & & & & 2 & 2 & & & & & 1 & 1 & & \\
\hline Germany & 3 & 3 & 0,0 & 1,8 & & & & & 3 & 3 & & & & & & & & \\
\hline Iceland & 1 & 1 & 0,0 & 0,6 & 1 & 1 & & & & & & & & & & & & \\
\hline India & 2 & 1 & $-50,0$ & 0,6 & 1 & & & & 1 & 1 & & & & & & & & \\
\hline Indonesia & 1 & 1 & 0,0 & 0,6 & & & & & & & & & & & 1 & 1 & & \\
\hline Ireland & 1 & 1 & 0,0 & 0,6 & & & & & & & & & 1 & 1 & & & & \\
\hline Italy & 1 & 1 & 0,0 & 0,6 & & & & & 1 & 1 & & & & & & & & \\
\hline Japan & 7 & 6 & $-14,3$ & 3,6 & 3 & 3 & & & 2 & 2 & 2 & 1 & & & & & & \\
\hline Netherland & 7 & 4 & $-42,9$ & 2,4 & 3 & & & & 2 & 2 & & & 1 & 1 & 1 & 1 & & \\
\hline New Zealand & 0 & 1 & 100,0 & 0,6 & & & & & & & & & & 1 & & & & \\
\hline Norway & 7 & 7 & 0,0 & 4,2 & 3 & 3 & & & 3 & 2 & & 1 & & & 1 & 1 & & \\
\hline Qatar & 0 & 1 & 100,0 & 0,6 & & 1 & & & & & & & & & & & & \\
\hline Saudi Arabia & 2 & 1 & $-50,0$ & 0,6 & 1 & 1 & 1 & & & & & & & & & & & \\
\hline South Africa & 1 & 1 & 0,0 & 0,6 & & & & & & & & & & & 1 & 1 & & \\
\hline South Corea & 3 & 3 & 0,0 & 1,8 & & & & & 2 & 2 & & & 1 & 1 & & & & \\
\hline Spain & 4 & 4 & 0,0 & 2,4 & 1 & 1 & & & 3 & 3 & & & & & & & & \\
\hline Sweden & 2 & 2 & 0,0 & 1,2 & 1 & 1 & & & 1 & 1 & & & & & & & & \\
\hline United Arab Emirates & 2 & 2 & 0,0 & 1,2 & & 1 & 1 & & & & & & & & 1 & 1 & & \\
\hline United Kingdom & 14 & 14 & 0,0 & 8,4 & 2 & 2 & & & 5 & 3 & & & 6 & 8 & 1 & 1 & & \\
\hline USA & 50 & 60 & 20,0 & 35,9 & 14 & 20 & 10 & 2 & 15 & 15 & & 1 & 3 & 10 & 8 & 12 & & \\
\hline TOTAL & 173 & 167 & & $100 \%$ & 51 & 55 & 18 & 2 & 52 & 49 & 11 & 10 & 18 & 24 & 23 & 27 & 0 & 0 \\
\hline
\end{tabular}

\section{FACILITY STATUS}

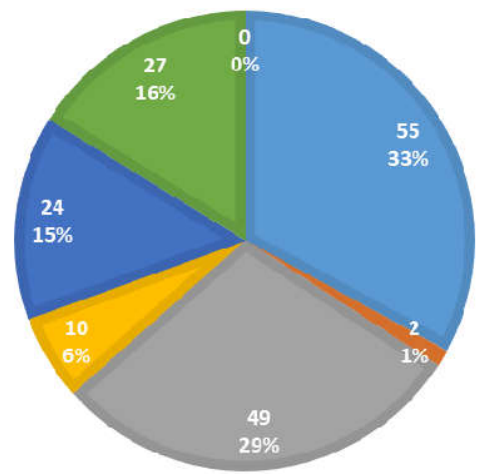

- Operational

moperation Suspended

- Completed

In Construction

Early Develupinent

Envanced Develnpment

- Development Planning

Source: Elaborated by author from Global CCS Institute

Graphic 3. Facility Status

\section{FACILITY STATUS 2020/2021}

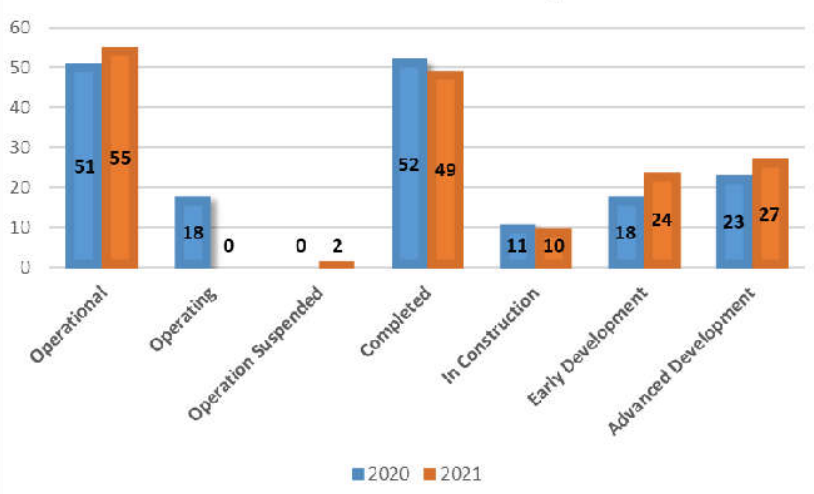

Source: Elaborated by author from Global CCS Institute

\section{Graphic 4. Facility Status 2020-2021}

Although it has increased about 2020, when the operational installations represented about $29 \%$ of the total, the installations in operation still represent only 1/3 of all, as observed in Graph 3 .
However, it is important to emphasize that there are about 61 installations in construction or projects being developed, which represents a great growth potential in the amount of $\mathrm{CO} 2$ captured and stored globally. Although the designation of facilities status has been changed since the last year by the Global CCS Institute, it is still possible to observe the increase in operational and under development facilities, as shown in Graph 4.

The table below, based on data from the Global Institute CCS, contains the most up-to-date data on CCS facilities distributed around the planet, including operational facilities - but not necessarily in operation at the moment, as well as projects under development. Although the status classifications of the facilities have been changed, it is still possible to observe and compare important aspects over the past year. Even in the COVID-19 scenario, there is a marked growth of facilities in both Australia and the United States, further increasing the representativeness of these countries. It is also important to note the start of operation of $\mathrm{CO} 2$ storage facilities in New Zealand and also Qatar, the latter being a country with great potential for expanding the use of this technology.

\section{CONCLUSION}

In general, the importance of the development of technology in the current environmental context is verified, as well as incentives for the use of CCS technology even in Brazil, either through public financing or fees on emissions, exploratory studies point to a potential for $\mathrm{CO} 2$ mitigation. Only for the petroleum provinces of the Pre-salt and the Recôncavo Basin, estimated according to the annual emissions capacity, a total of $26.4 \mathrm{Mt} \mathrm{CO} 2$ / year mitigated. Studies reveal that Brazil's possible geological reservoirs for storage are approximately $2000 \mathrm{Gt}$ (billions of tons) of CO2. (CAMARA, 2011).

The implementation of CCS activities in Brazil and worldwide and the development of associated technologies are vital for reducing a significant amount of carbon dioxide in the atmosphere in the coming decades. However, due to the numerous aspects covered, whether in the technical or operational aspect, the CCS must be treated at the international level as a project, that is, with the elaboration of clear proposals and feasible goals for implementation - according to the Paris Agreement - with the establishment of tonnage targets for 
carbon dioxide captured and stored, methods of encouraging public and private investments, formal agreements closed and approved by the Legislative and Executive branches of the countries (NUNES; COSTA, 2019). The creation of programs for the recognition and dissemination of $\mathrm{CO} 2$ capture and storage practices should also be encouraged to disseminate technology to the general population and gain the confidence and support of public opinion (NUNES; COSTA, 2019). In the meantime, governmental entities, private initiative, and international organizations must cooperate in favor of a safe, legal environment for CCS activities in Brazil, with the clear establishment of rights and duties, operating conditions, and decommissioning of projects as well as specific guidelines for all the phases of the projects (NUNES; COSTA, 2019).

\section{ACKNOWLEDGMENT}

The authors gratefully acknowledge support from FAPESP and SHELL Brasil through the 'Research Centre for Gas Innovation RCGI' (FAPESP Proc. 2014/50279-4), hosted by the University of Sao Paulo, and the support given by ANP (Brazilian National Oil, Natural Gas and Biofuels Agency) through the R\&D levy regulation.

\section{REFERENCES}

Almeida, A. S. et al. 2010. A study on the potential for CCGS in the Pre-salt cluster of Santos Basin: the Tupi pilot application. In: Rio Oil \& Gas Expo and Conference 2010. Copyright 2010, Rio de Janeiro. Anais... Rio de Janeiro: Instituto Brasileiro de Petróleo, Gás e Biocombustíveis - IBP, Setembro de.

Bachu, S., Gunter W. D, Perkins, E.H. 1994. Aquifer disposal of $\mathrm{CO} 2$ : hydrodynamic and mineral trapping, Energy Conversion and Management, 35 (4), pp. 269-279.

Beck, Brendan et al. 2011. The Current Status of CCS development in brazil. Energy Procedia.

Câmara, George et al. 2011.Tecnologia de armazenamento geológico de dióxido de carbono: panorama mundial e situação brasileira. Revista Eletrônica Sistenas \& Gestão. Volume 6, Número 3, pp. 238-253v

Easac 2013. European Academies Science Advisory Council - Carbon capture and storage in Europe. Halle.
Epe - Empresa de Pesquisas Energéticas - 2018. Estocagem Subterrânea de Gás Natural - Aspectos Gerais, Regulatórios, Estimativa de Custos e Simulação. http://www.epe.gov.br/sitespt/publicacoes-dados-abertos/publicacoes/PublicacoesArquivos/ publicacao-337/EPE, $\% 202018 \% 20-\% 20$ Estocagem $\% 20$ Substerr\%C3\%A2nea\%20de\%20G\%C3\%A1s\%20Natural.pdf Acesso: 17/09/2019.

Global CCS Institute - Disponível em: <https://www.netl.doe. gov/coal/carbon-storage/faqs/carbon-storage-faqs $>$. Acessado em: 13 jun. 2019. >. Acessado em: 01 mar. 2020.

Goraieb, C.L.;Iyomassa, W.S.; Appi, C.J. 2005. Estocagem Subterrânea de Gás Natural: Tecnologia Para Suporte ao Crescimento do Setor de Gás Natural no Brasil. Editora: IPT. São Paulo, SP, 2005. 226p.

Iea (2010) Carbon Capture and Storage- Model Regulatory Framework. Paris: OECD/IEA, 130pp.

Ipcc, Carbon Dioxide Capture and Storage, Special Report, B. Metz, Etc, Cambridge University Press, United Kingdom, 2005.

Ketzer, João Marcelo Medina et al., Atlas brasileiro de captura e armazenamento geológico de CO2. Porto Alegre, EDIPUCRS, 2016.

Metz, B., et al. IPCC Special Report on Carbon Dioxide Capture and Storage. Prepared by Working Group III of the Intergovernmental Panel on Climate Change, 2005, 443pp.

Milani, E.K. et al. 2007. "Bacia do Paraná". Boletim de Geociências da Petrobrás, v. 15(2), pp. 265-287.

National Energy Technology Laboratory - Disponível em: $<$ https://www.netl.doe.gov/coal/carbon-storage/faqs/carbonstorage-faqs $>$. Acessado em: 13 jun. 2019.

Noaa - National Oceanic and Atmospheric Administration (2020). Climate Change: Atmospheric Carbon Dioxide. Available: https://www.climate.gov/news-features/understandingclimate/climate-change-atmospheric-carbon-dioxide Access in: $15 / 07 / 2020$

Nunes, Romario; COSTA, Hirdan Katarina de M. Operação e fechamento de instalações de armazenamento para atividades de CCS no Brasil. In: Costa, Hirdan Katarina de Medeiros (org.). Aspectos Jurídicos da Captura e Armazenamento de Carbono. Rio de Janeiro: Lumen Juris, 2019

The Global Status Of Ccs 2017- Disponível em: https:/www.globalccsinstitute.com/wp-content/uploads/ 2018/12/ 2017-Global-Status-Report.pdf $>$. Acessado em: 01 mar. 2020.

Zoback, M. 2007. Reservoir Geomechanics. Cambridge: Cambridge University Press. doi:10.1017/CBO9780511586477. 